\title{
INNOVATION ACTIVITY IN AGRICULTURE AND THE ISSUES OF ITS ASSESSMENT
}

\section{Natalia Bannikova', NataliaTelnova², Victoria Markarova $^{3}$}

\begin{abstract}
The article describes the level of innovative activities of Russian agricultural businesses based on currently accepted indicators and justifies the limitations for their application in agriculture, taking into account its peculiar features. As an example the article considers a large agro-holding, which conducts active innovative activities aimed at the development of precision agriculture. The article shows the potential of correlation-regression analysis for the detection of the influence of particular technological innovations on the obtained result, as well as the potential of timeseries analysis for the assessment of major agriculturally-significant climatic risks.
\end{abstract}

Key words: innovative activities, agriculture, innovations efficiency assessment, risks. JEL $^{4}$ : O31, Q16

\section{Introduction}

Classical economic analysis proceeds from the premise that sustainable economic growth is achievable only on the basis of systematic innovative activities supported by the companies of all sectors of economy. Therefore, contemporary agricultural policy of industrialized and most of newly-industrialized countries focuses on stimulating the development and adoption of advanced technologies, which are significantly more productive than traditional ones. Many of traditional agricultural technologies have approached to their upper limit of productive potential, which is followed by steep reduction of the return on investments in their development. Consequently, innovation-based development is a high-priority task for individual and national agricultural businesses alike.

1 Natalia Bannikova, Ph.D., Doctor of Economic Sciences, Full Professor, Stavropol State Agrarian University, Zootekhnichesky Side-Street no. 12, 355017 Stavropol, Russian Federation, Phone: +79 283623 409, E-mail: nbannikova@mail.ru

2 Natalia Telnova, Ph.D., Candidate of Economic Sciences, Senior Lecturer, Stavropol State Agrarian University, Zootekhnichesky Side-Street no. 12, 355017 Stavropol, Russian Federation, Phone: +79 280109 187, E-mail: telnatnik@mail.ru

3 Victoria Markarova, M.A., Ph.D. Student, Stavropol State Agrarian University, Zootekhnichesky Side-Street no. 12, 355017 Stavropol, Russian Federation, Phone: +79 682745 343, E-mail: vamarkarova@npo-nhp.com

4 Article info: Original Article, Received: 22 ${ }^{\text {nd }}$ December 2020., Accepted: 29 $9^{\text {th }}$ January 2021. 
However, even though the need for innovative modernization is quite obvious, the increase of innovative activities in agriculture still remains a topical issue for many countries. This is proved by the review of most recent publications. Researchers are primarily interested in external factors that restrain the distribution of different innovations (Lachman, López, 2019; Greenland et al., 2019). Attention is also paid to internal barriers (Borges et al., 2019; Aboal et al., 2019). At the same time, data on the significance of various factors of restraint, which is obtained from different researches, are discrepant. This is quite explainable because experts suppose that territorial peculiarities are of great importance by the creation of innovation systems in agricultural business (García Sánchez et al., 2018).

The problem of innovative development of Russian agriculture is also extremely urgent, because innovative activity of agricultural businesses in Russia is estimated as very low (Scientific consultant, 2016; Pershukevich et al., 2018; Bogachev, 2019).

Another issue is the assessment procedure of innovative activities. The issues of assessing not only companies' innovative activities, but also the efficiency of particular innovations have not been resolved. Despite the multi-year researches in this field the problem has not been unambiguously settled (Bucci et al., 2019; Marinchenko et al., 2019; Makarova, 2019).

The purpose of the present research is to study the innovative activities of Russian agricultural businesses and to improve the procedures for innovations assessment considering industry-specific peculiarities.

\section{Methods of the research and data sources}

Theoretical and methodological justification is represented by the scientific papers of Russian and foreign researchers who consider the issues of agricultural innovation-driven development. The research was performed based on abstract-logical and comparative methods. The influence of particular elements of innovative technologies on the obtained results was estimated with the use of correlation-regression analysis, whereas risks were estimated with the use of statistical methods of variation measurement.

Informational and empirical basis of the research is represented by the data of annual statistical reports of the bodies of the Federal State Statistics Service (FSSS), the results of researches by National Research University Higher School of Economics (NRUHSE) and the data of monitoring innovative activities in agriculture. The innovative activities of Agro-holding Irrico Group, a large manufacturer of agricultural products in Stavropol region, one of the major agricultural regions in Russia, were used as a specific example. Internal reporting data and in-depth interview with managing authorities of Agro-holding were the source of information. 


\section{Results}

The development of science and technology in Russia is not sufficiently dynamic as compared to other countries. Thus, according to the data of National Research University Higher School of Economics the overall level of businesses' innovative activities is $8.5 \%$. For comparison, the value of this indicator in Serbia is $43.4 \%$ (NRUHSE, 2019).

The comparative analysis of data relating to innovative activities in different sectors of Russian economy reveals that the occurrence of innovations in agriculture is even lower. Data provided in Table 1. describes the contribution of agriculture to innovative development of Russian economy as minor.

Table 1. Indicators of companies' innovative activities in Russia (in 2016-2017., in \%)

\begin{tabular}{|c|c|c|c|c|c|c|}
\hline \multirow[t]{2}{*}{ Indicators } & \multicolumn{2}{|c|}{ Agriculture } & \multicolumn{2}{|c|}{$\begin{array}{l}\text { Industrial } \\
\text { production }\end{array}$} & \multicolumn{2}{|c|}{$\begin{array}{l}\text { Total in } \\
\text { economics }\end{array}$} \\
\hline & 2016 & 2017 & 2016 & 2017 & 2016 & 2017 \\
\hline $\begin{array}{l}\text { The share of innovative goods in total } \\
\text { shipping volume }\end{array}$ & 1.4 & 1.8 & 8.4 & 6.7 & 8.5 & 7.2 \\
\hline Overall level of innovative activities & 4.0 & 3.7 & 10.5 & 10.5 & 8.4 & 8.5 \\
\hline $\begin{array}{l}\text { The share of companies that } \\
\text { implement technological innovations }\end{array}$ & 3.4 & 3.1 & 9.2 & 9.6 & 7.3 & 7.5 \\
\hline
\end{tabular}

Source: Authors' calculation based on FSSS, 2018.

It is impossible to analyse the dynamic changes in innovative activities of agricultural businesses within long period of time because the accumulation of statistical data referring to innovative activities in agriculture has begun since 2016. This could be another indirect evidence of insufficient attention to innovative modernization of the sector in previous years.

Simultaneously, the cross-industry comparison of companies' innovative activities can hardly be fully considered due to peculiarities of agrarian production. Literary sources provide rather detailed consideration of peculiarities of innovative processes in agriculture. Their analysis and summary with regard to the objectives of conducted research allows highlighting the following particular features:

- limited potential for product innovations since agriculture produces mostly standardized products, which serve as a basis for innovative products further manufactured by food industry companies;

- diverse soil and climatic conditions in agricultural production, as well as the variety of crops and species predetermine significant differences in used production technology and obtained results; 
- duration and higher risks of scientific researches related to biological objects (plants, animals, soil microorganisms, etc.);

- only large and financially successful agricultural corporations can afford realisation of appropriate proprietary scientific researches and purchase of expensive state-of-the-art equipment, whereas the most of the companies in agriculture are small and cannot manage the expensive innovations without government support;

- as a rule, in their nature, agricultural innovations are enhancing and not revolutionary.

All of the above peculiarities impose constraints on the application of indicators, which characterize the innovative activities of companies in other sectors. For example, following system of indicators for industrial companies is recommended by experts:

- product novelty factor;

- knowledge intensity of the company;

- factor of modernization of production efficiency;

- R\&D cost-effectiveness ratio;

- R\&D intensity factor (Somenkova, 2017).

According to the analysis of mentioned and some other indicators provided in Table 2. they are not applicable or they are only partially applicable to agricultural businesses. Obviously, the assessment of innovative activities in agriculture, as one of the tools for its stimulation, needs to be improved.

The problem of more accurate assessment of new technologies' advantages is yet another obstacle for the enhancement of innovative activities by agricultural companies. Moreover, this problem is also topical for the countries with welldeveloped agriculture (Bucci et al., 2019). The link between the use of new technologies and production output is not close enough due to the influence of natural factors. Consequently, the risks that innovative activities will not produce expected results are even higher in agriculture as compared to other sectors of economy. It can be underlined that agriculture-specific risks have multiplicative effect upon the risks of innovative activities in agricultural business. Therefore, the assessment of agricultural innovations requires more detailed characteristics of influencing factors and derived results. 
Table 2. The indicators of companies' innovative activities

\begin{tabular}{|c|c|c|}
\hline No. & Indicator & Peculiarities of application in agriculture \\
\hline 1. & Product novelty factor & $\begin{array}{l}\text { Is mostly applicable for the assessment of new seed } \\
\text { varieties or hybrids and animal breeds }\end{array}$ \\
\hline 2. & $\begin{array}{l}\text { Knowledge intensity of the } \\
\text { company }\end{array}$ & \multirow{3}{*}{$\begin{array}{l}\text { The adoption of the majority of new agricultural } \\
\text { technologies does not require carrying out independent } \\
\text { researches; new technologies are tested under routine } \\
\text { operation and do not require significant additional } \\
\text { expenses }\end{array}$} \\
\hline 3. & R\&D cost-effectiveness ratio & \\
\hline 4. & R\&D intensity factor & \\
\hline 5. & $\begin{array}{l}\text { Modernization efficiency factor } \\
\text { of the production }\end{array}$ & $\begin{array}{l}\text { Equipment modernization, which is the most essential } \\
\text { for agriculture, influences the quality of technological } \\
\text { operations and not the innovation of the products }\end{array}$ \\
\hline 6. & $\begin{array}{l}\text { Average timespan needed to } \\
\text { develop one innovation }\end{array}$ & $\begin{array}{l}\text { The duration of agricultural scientific researches depends } \\
\text { on the peculiarities of biological objects }\end{array}$ \\
\hline 7. & $\begin{array}{l}\text { Coefficient of financing } \\
\text { innovative activities }\end{array}$ & $\begin{array}{l}\text { Many agricultural businesses are short of own funds, } \\
\text { therefore their ability to self-finance innovative activities } \\
\text { is limited }\end{array}$ \\
\hline
\end{tabular}

Source: According to author's opinion.

As an example it will be considered the innovative activities of Agro-holding Irrico Group located in one of the major Russian agricultural regions - Stavropol region Agro-holding was established in 2012. It owns 21 thousand ha of arable land, including 6.5 thousand ha of irrigated area. This large agricultural formation is rather successful, as its net profit is reaching 3,700 thousand USD in certain years. Such financial potential allows adopting new technologies at Holding's own expense.

The activity of Agro-holding in innovation sector focuses on the development of precision agriculture, which is deemed one of the most promising modern agricultural innovation systems. The deterrent for the distribution of precision agriculture for many companies is its high-cost and technical difficulty because this system of managing crop productivity uses satellite-based and computer technologies. At the same time the specific feature of precision agriculture is its complexity, as it comprises a variety of individual technologies. The need for their adoption, as well as the order of implementation priority is determined by the company's management. Thus, the innovative project devoted to the adoption of precision agriculture is usually long term and comprises several stages. Therefore it should be flexible with stage-by-stage adjustments based on achieved results and foreseeable risks. The lack of practical experience in the application of precision agriculture requires sufficient accuracy in course of project efficiency estimation under different conditions.

The example of a stage-by-stage approach to innovative activities is provided by Agro-holding Irrico Group. As a first step in the adoption of precision agriculture 
there were purchased three EasyPilot parallel driving systems (with up to $10 \mathrm{~cm}$ accuracy) to equip the New Holland's tractors. After the first two seasons of their use gained results were generally estimated as positive: average saving of fertilizers and pesticides amounted up to $15 \%$ as compared to pre-set consumption rate. However, the most accurate assessment of the influence of parallel driving systems on the obtained results can be performed only with consideration of changes in total product output. Such assessment is complicated, because crop yield was also influenced by changes in the rates of seeding, irrigation and fertilizer-application.

In order to make the assessment of results more accurate it was suggested the use of correlation-regression analysis of data received from experimental fields and from fields with standard crop cultivation technology (there were 32 observations).

Potato yield ( $\mathrm{t} / \mathrm{ha}$ ) was used as dependent variable $(\mathrm{Y})$ and yield-influencing factors were:

$\mathrm{X}_{1}$ - seeding rate, in $\mathrm{t}$;

$\mathrm{X}_{2}$ - nitrogen-fertilizer application rate, in $\mathrm{kg} / \mathrm{ha}$;

$\mathrm{X}_{3}$ - potassium- fertilizer application rate, in $\mathrm{kg} / \mathrm{ha}$;

$\mathrm{X}_{4}$ - phosphate-fertilizer application rate, in $\mathrm{kg} / \mathrm{ha}$;

$\mathrm{X}_{5}$ - irrigation rate, in $\mathrm{m}^{3} / \mathrm{ha}$;

$\mathrm{X}_{6}$ - soil preparation by a tractor, equipped with parallel driving system (in binary system, where 0 - no, 1 -yes).

The received multi-regression model is of high representativeness with determination coefficient $\mathrm{R}^{2}$ being equal to $80.5 \%$. This means that the selected factors are highly likely to exert influence on the dependent variable. The results of correlation analysis show that out of six variables $\mathrm{X}_{5}$ and $\mathrm{X}_{6}$ are most closely connected with the resultant factor (correlation coefficients are 0.785 and 0.783 accordingly).

$\mathrm{X}_{6}$ variable is of greatest interest since it directly characterizes the use of innovation technology in terms of current research. Dual linear regression model is given by $\mathrm{Y}=28.14+6.67 \mathrm{X}_{6} \mathrm{R}^{2}$ determination coefficient is rather high and equals $61.4 \%$, meaning that there is direct dependence between crop yield and the availability of parallel driving system on the tractor. The results can be interpreted as follows: equipping one more tractor with parallel driving system will facilitate potato yield increase by $6.7 \mathrm{t} / \mathrm{ha}$ on the fields, where technological operations with the use of innovative equipment were used. 
Therefore, the intention of Agro-holding to purchase additional three EasyPilot parallel driving systems and two Autopilot systems should be considered quite reasonable. Autopilot systems are more accurate (accuracy up to $2 \mathrm{~cm}$ ) and more expensive. However, they are needed for growing vegetables that require min 5 $\mathrm{cm}$ accuracy of technological operations. The total cost of investment program for the second stage of precision agriculture adoption (including the purchase of sensors to control moisture, temperature and equipment components, etc.) is more than 260 thousand USD.

Such a high-cost decision requires previous assessment of its potential effects, as well as consideration of possible risks, which can be faced in course of achieving such effects. This is particularly essential for agriculture due to environmental uncertainty in course of innovative project implementation (natural and climatic, social and political, demographic risks, etc.), which represents an additional risk factor for innovative activities. The most important are weather-related risks since their destabilizing effects in Russia remains quite significant. This can be observed from the comparison of unfruitful 2010 and record 2008 and 2016. Insignificant changes of agro-technical conditions caused the reduction of gross yield of grain in the country for approximately 50-55 million t/year, i.e. almost by 2 times (FSSS, 2018). The significance of natural and climatic risks for the implementation of innovative projects in agriculture increases also due to relative decrease of significance of other risks related to innovative activities: the risk of introducing a product with innovative properties to the market, the risk of insufficient $R \& D$ patent protection, etc.

Different methods for the assessment of natural and climatic risks in agriculture are quite thoroughly studied in literature. At the same time, complex statistical methods as a basis use the data of many companies, intended for the development of insurance system, management of regional agricultural complexes, etc. Not all of these methods are applicable for the assessment of risks by a separate company with much more limited informational database and the deficiency of experts able to perform complicated calculations. Therefore, in this case it is reasonable to use more simple statistical methods combined with expert assessments. In particular, one of such methods is time-series analysis. Usually, conventional variation indicators (dispersion, mean-square deviation, variation coefficient) are used for the assessment of natural and climatic risks for agricultural production. However, these variability measurers equally display positive and negative deviations, although negative deviations are mostly significant for company's system of risks assessment and management. 
Therefore, Chepurko V. V. recommends supplementing the conventional variation indicators with the coefficient of mean negative variability (sum of negative deviations to mean level of series) and the coefficient of mean maximum negative variability, which is calculated by the following formula (Chepurko, 2019):

$$
\mathrm{K}=\left[\sum \frac{\left(X_{n}-X_{a n}\right)}{m}\right] / Y_{a}
$$

Where,

$X_{n}$ - negative deviation of actual level of series from the mean (or from the trend, if available), which is higher than the mean negative deviation;

$\mathrm{X}_{\mathrm{an}}$ - the mean negative deviation;

$\mathrm{Y}_{\mathrm{a}-}$ the mean level of series;

$\mathrm{m}$ - number of negative deviations, which exceed mean negative deviation

These methods were used for the comparative assessment of risks for the expected yield of early potato and onion in Agro-holding Irrico Group. Calculations were made based on the data from two companies, which have been a part of Agro-holding for 6 years.

Table 3. Indicators of crop-yield variation

\begin{tabular}{|l|c|c|}
\hline \multicolumn{1}{|c|}{ Indicators } & Early potato & Onion \\
\hline Variation coefficient & 0.21 & 0.17 \\
\hline Coefficient of mean negative variability & 0.90 & 0.69 \\
\hline Coefficient of mean maximum negative variability & 0.29 & 0.21 \\
\hline
\end{tabular}

Source: According to author's calculation.

The information in Table 3 . shows that early potato production is not only less stable, but is also more risky in terms of potential reduction of productivity. The availability of this data enables company experts to perform a more profound factor analysis of instability reasons and to select innovative technological practices in order to improve the situation. Obtained coefficients can be used to justify the discount rate during the assessment of risks relating to innovative project and to develop adequate management decisions. 


\section{Conclusion}

The innovative activity of agricultural businesses in Russia is estimated as very low. However, cross-industry comparison cannot be considered entirely objective. Some indicators, which characterize the innovative activity of companies in other sectors, can be used in agriculture with certain limitations. Presumably, the improvement of assessment methods for the innovative activities of agricultural businesses requires further investigations.

The issue of efficiency assessment of innovative technologies in agriculture also cannot be deemed as fully resolved, which is primarily because of higher risks of innovative activities due to additional influence of agriculture-specific risks. The obtained result (particularly, crop yield) is the result of exposure of different technological and natural factors. For example, in unfruitful years there was a decrease of gross yield of grains in Russia for almost 2 times compared to favourable years.

Upon the availability of required detailed data correlation-regression analysis is able to determine the influence of particular elements of innovative technologies and to perform more accurate assessment of the results of implementation for the stages of large innovative projects in order to adjust subsequent stages, if necessary. The assessment of natural and climatic risks in course of planning the innovative activities requires a more comprehensive approach to the investigation of variability of received results and to the possibility of negative deviations occurrence. For example, the use of two additional coefficients characterizing negative fluctuations made it possible to determine the need for in-depth factor analysis of early potato production.

\section{References}

1. Aboal, D., Mondelli, M., Vairo, M. (2019). Innovation and productivity in agricultural firms: evidence from a country-wide farm-level innovation survey. Economics of Innovation and New Technology, 28(6):616-634.

2. Bogachev, A. I. (2019). Innovative activity in agriculture of Russia: modern trends and challenges. Bulletin of the NGIEI, 5(96):95-106.

3. Borges, J. A. R., Oude Lansink, A. G. J. M., Emvalomatis, G. (2019). Adoption of innovation in agriculture: A critical review of economic and psychological models. International Journal of Innovation and Sustainable Development, 13(1):36-56.

4. Bucci, G., Bentivoglio, D., Finco, A. (2019). Factors affecting ICT adoption in agriculture: A case study in Italy. Quality - Access to Success, 20(S2):122-129. 
5. Chepurko, V. V. (2019). Methodical approach to the assessment of regionalcrop risk in agrarian production. Scientific notes of the Crimean engineering and pedagogical university, 1(63):206-213.

6. FSSS (2018). Russian Statistical Yearbook - 2018. Federal State Statistics Service, Moscow, Russian Federation, retrieved at: www.gks.ru/free_doc/doc_2018/year/ year18.pdf, $10^{\text {th }}$ April 2020.

7. García Sánchez, E. I., Vargas Canales, J. M., Palacios Rangel, M. I., Aguilar Avila, J. (2018). The innovation system as an analytical framework for protected agriculture in the Mexican central region. Cuadernos de Desarrollo Rural, 15(81):1-24.

8. Greenland, S., Levin, E., Dalrymple, J. F., O’Mahony, B. (2019). Sustainable innovation adoption barriers: water sustainability, food production and drip irrigation in Australia. Social Responsibility Journal, 15(6):727-741.

9. Lachman, J., López, A. (2019). Innovation obstacles in an emerging high tech sector: The case of precision agriculture in Argentina, Management Research, 17(4):474-493.

10. Makarova, I. V. (2019). Methodology of statistical measurements and innovation assessment in industry. Presentation, Institute of Economics URO RAN, Moscow, Russia, retrieved at: www.gks.ru/free doc/new_site/rosstat/NMS/ prez-M-160915.pdf, $10^{\text {th }}$ April 2020.

11. Marinchenko, T. E., Kuzmin, V. N., Korolkova, A. P., Goryacheva, A. V. (2019). The results of innovation activities and scientific and technological development of agriculture: Scientific and analytic overview, Rosinformagrotekh, Moscow, Russian Federation, p. 232.

12. NRUHSE (2019). Indicators of innovative activity: Statistical digest. National Research University, Higher School of Economics, Moscow, Russia, p. 376.

13. Pershukevich, I. P., Ryabukhina, T. M., Zyablitseva, Ya. (2018). The science underlying the innovative capabilities of agricultural organizations. Fundamental research, 1:106-110.

14. Scientific consultant(2016). Methodologicalapproachesofinnovation-investment activity development in AIC. Scientific consultant, Moscow, Russian Federation, p. 105, retrieved at: https://elibrary.ru/download/elibrary_26215670 59288461 . pdf, $10^{\text {th }}$ April 2020.

15. Somenkova, N. S. (2017). Improvement of a technique of efficiency assessment of innovative development of the enterprise. Russian Journal of Entrepreneurship, 18(5):945-956. 